Proc. Estonian Acad. Sci. Geol., 2004, 53, 3, 190-209

\title{
Svecofennian metamorphic zones in the basement of Estonia
}

\author{
Väino Puura ${ }^{\mathrm{a}}$, Rutt Hints ${ }^{\mathrm{a}, \mathrm{e}}$, Hannu Huhma ${ }^{\mathrm{b}}$, Vello Klein ${ }^{\mathrm{c}}$, Mare Konsa ${ }^{\mathrm{d}}$, \\ Reedik Kuldkepp ${ }^{\mathrm{a}}$, Irmeli Mänttäri ${ }^{\mathrm{b}}$, and Alvar Soesoo ${ }^{\mathrm{d}}$ \\ a Institute of Geology, University of Tartu, Vanemuise 46, 51014 Tartu, Estonia; vaino.puura@ut.ee \\ ${ }^{\mathrm{b}}$ Geological Survey of Finland, P.O. Box 96, FIN-02151 Espoo, Finland \\ ${ }^{c}$ Geological Survey of Estonia, Kadaka tee 82, 12816 Tallinn, Estonia \\ ${ }^{d}$ Institute of Geology at Tallinn University of Technology, Estonia pst. 7, 10143 Tallinn, Estonia \\ e Estonian Museum of Natural History, Lai 29A, 10133 Tallinn, Estonia
}

Received 14 August 2003, in revised form 20 April 2004

\begin{abstract}
Svecofennian (Palaeoproterozoic) orogenic, folded metamorphic rocks dominate in the basement structure in Estonia. In northern Estonia (Tallinn zone), supracrustal rock associations (metavolcanic and -sedimentary sequences), their structure and amphibolite metamorphic grade resemble the Svecofennian metamorphic island arc suites of southern Finland. In northeastern Estonia, the metapelitic sequences of the Alutaguse zone resemble those of the NE marginal metasedimentary basins of the Svecofennian orogen, as studied in the St. Petersburg District (NW Russia) and SE Finland. Local variations of the metamorphic grade, related to fault zones or local metamorphic domes (metamorphosed up to granulite assemblages) feature the amphibolite facies areas of northern Estonia. In southern Estonia, tectonically undefined, predominantly mafic metavolcanics are of granulite metamorphic grade. The granulite region of southern Estonia and northern Latvia is much larger than known in the 1.9-1.8 Ga Svecofennian metamorphic zones of southern Finland. The peak conditions of granulite metamorphism in Estonia at ca. $800{ }^{\circ} \mathrm{C}$ and $4-6 \mathrm{kbar}$ resemble those of the Pielavesi granulites (Proterozoic), central Finland. However, the U-Pb age of $1778 \pm 2 \mathrm{Ma}$ for monazite and the Sm-Nd age of $1728 \pm 24$ Ma for garnet from the sample Kõnnu 3005150 are clearly younger than any comparable results from Finland, and suggest that the granulite facies metamorphism in southern Estonia is distinct from that recorded in southern and central Finland.
\end{abstract}

Key words: metamorphism, P-T-conditions, age, Palaeoproterozoic, Estonian basement.

Abbreviations: $\mathrm{Bi}=$ biotite, $\mathrm{Pl}=$ plagioclase, $\mathrm{Kfs}=$ potassium feldspar, $\mathrm{Gr}=$ garnet , $\mathrm{Cor}=$ cordierite Sil = sillimanite,$\quad \mathrm{Hbl}=$ hornblende, $\mathrm{Px}=$ pyroxene,$\quad \mathrm{Hyp}=$ hypersthene,$\quad$ And $=$ andalusite , $\mathrm{Mu}=$ muscovite,$\quad \mathrm{Mi}=$ microcline, $\mathrm{Q}=$ quartz,$\quad \mathrm{Sp}=$ spinel,$\quad \mathrm{Ep}=$ epidote,$\quad \mathrm{Ap}=$ apatite, $\mathrm{Carb}=$ carbonates, $\mathrm{Opx}=$ orthopyroxene, $\mathrm{Mpx}=$ monocline pyroxene, $\mathrm{Wr}=$ whole rock, $\mathrm{Cpx}=$ clinopyroxene. 


\section{INTRODUCTION}

Metamorphic rocks predominate in the Precambrian basement of Estonia. Earlier mapping of the buried basement rocks was performed using regional potential geophysical field (gravity, magnetic mapping) and drill core studies of more than 500 drill holes. These metamorphic belts belong to the uniform Svecofennian crustal domain spreading over 1 million $\mathrm{km}^{2}$ in the western corner of the East European Craton. Within this domain, metamorphic zones from low- to high-grade metamorphism have been observed. Within Estonian basement, the rocks of high-grade amphibolite to granulite facies dominate. Detailed studies, however, have revealed widespread spatial variations in the metamorphic grade. Metamorphic gradients related to fault zones, semicircular or belt-form areas of increasing metamorphic grade (metamorphic domes) feature the general high-grade metamorphic field. In this paper we present an overview of detailed studies of metamorphism of Estonian basement rocks. The paper deals with the composition of metamorphosed supracrustal rocks, variation in their mineralogical composition, and regional and local estimates of metamorphic pressure-temperature $(\mathrm{P}-\mathrm{T})$ conditions and ages.

\section{COMPOSITION AND REGIONAL SETTING OF THE ESTONIAN METAMORPHIC COMPLEXES}

The structural zones distinguished in the basement of Estonia substantially vary in metamorphic lithologies. Previous studies have revealed that primary supracrustal suites are represented by a large variety of mafic, intermediate, and acidic volcanic rocks as well as clastic sediments from clays to sands, in places with carbonate admixture (Koppelmaa et al. 1978; Puura et al. 1983; Klein 1986). Additional information on the protoliths of the metamorphic rocks has been obtained studying typologies of zircons (Konsa 1986; Konsa \& Puura 1999).

The average mineral contents of different supracrustal rocks in the Tallinn and Alutaguse structural zones (Fig. 1) are calculated from the drill core data. Al-rich garnet- (Gr), cordierite- (Cor) and sillimanite- (Sil) bearing gneisses and biotite (Bi) gneisses build up $25.4 \%$ and $90.45 \%$, respectively; Bi-plagioclase (Pl)-Kfs (potassium feldspar)-bearing gneisses $-24.4 \%$ and $1 \%$, respectively; Bi-Pl, Bihornblende-(Hbl)-Pl and pyroxene (Px)-Pl gneisses and amphibolites - 50.2\% and $6.1 \%$, respectively (Klein 1986). In southern and western Estonia, pyroxeneor hornblende-bearing mafic metavolcanic rocks dominate, respectively, whereas metapelites and granitogneisses are rare. In Fig. 2 mineral compositions, as calculated from the mineralogical analyses of optical microscopy, reflect both the distribution of rock types and their mineralogical assemblages in the four main structural zones of the Estonian basement. Within the local structural units of the Alutaguse zone, such as Tapa, Haljala, Assamalla, Uljaste, and Jõhvi (Fig. 1), rock associations and mineral assemblages are much more variable (Fig. 2; Klein 1986). 


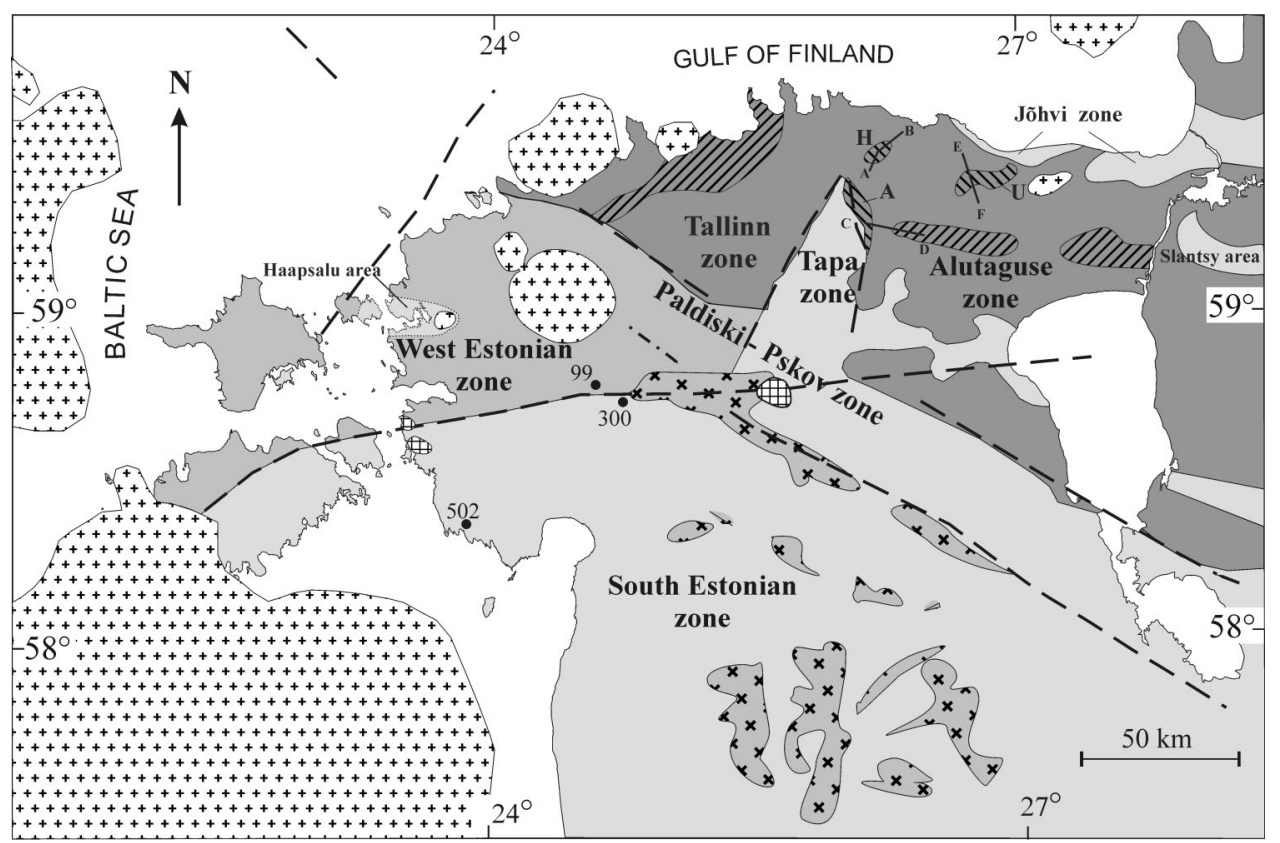

$\because \because++$ Rapakivi massifs

$\times \times$ Microcline granitoids

\#曲 Taadikvere and Virtsu post-orogenic massifs

Dominant areas of $\quad \square$ Dominant areas of retrogranulite metamorphic facies grade metamorphic facies

AIIV Higher-grade amphibolite $\mathbb{Z} I I / \wedge$ Lower-grade amphibolite facies facies

- - Shear or thrust zones $\quad-\quad$ Profiles presented in the basement in Fig. 3

Dominant areas of amphibolite metamorphic facies

Local areas of higher-grade amphibolite facies: A, Assamalla; H, Haljala; U, Uljaste

Fig. 1. Map of metamorphic zones of the Estonian basement (modified from Klein 1986).

Generally, pre-metamorphic textural features in high-grade metamorphic and migmatized rocks have been obliterated. However, occasionally graded bedding is observed in metapelites. Sedimentary protoliths of metapelites in the Tallinn and Alutaguse zones are supported by findings of zoned zircons, whose rounded cores suggest their detrital origin (Konsa \& Puura 1999). The distinction of the sedimentary or volcanic origin of metamorphic suites, especially in cases of $\mathrm{Ca}$ rich composition reminding of mafic volcanics, has been made using the bulk chemical composition and spatial relationships of metamorphic rock suites in core sequences (Puura et al. 1983). Metamorphic and migmatization-related zircons void of detrital varieties or cores confirm the volcanic origin of many mafic protoliths (Konsa \& Puura 1999). 


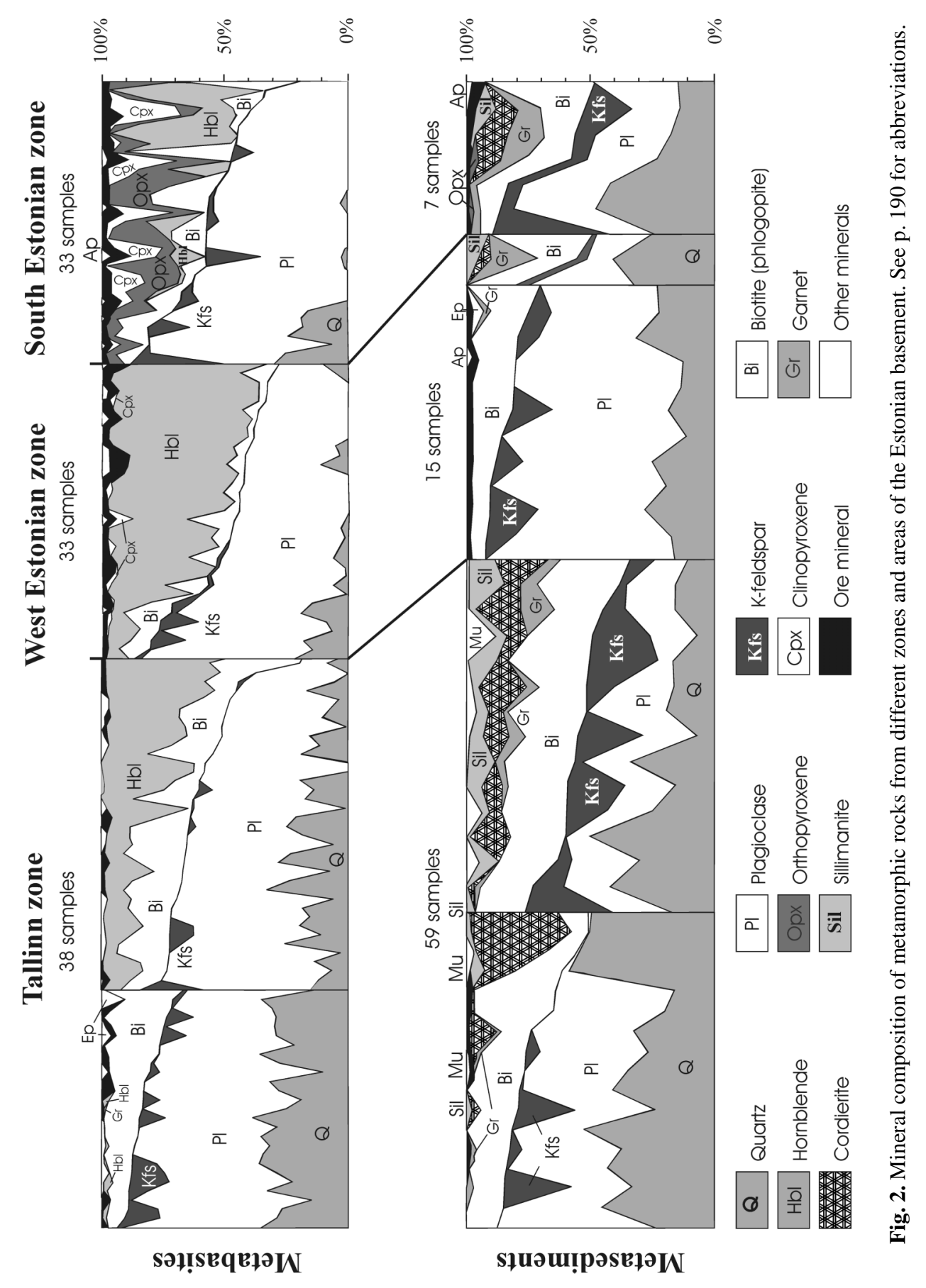




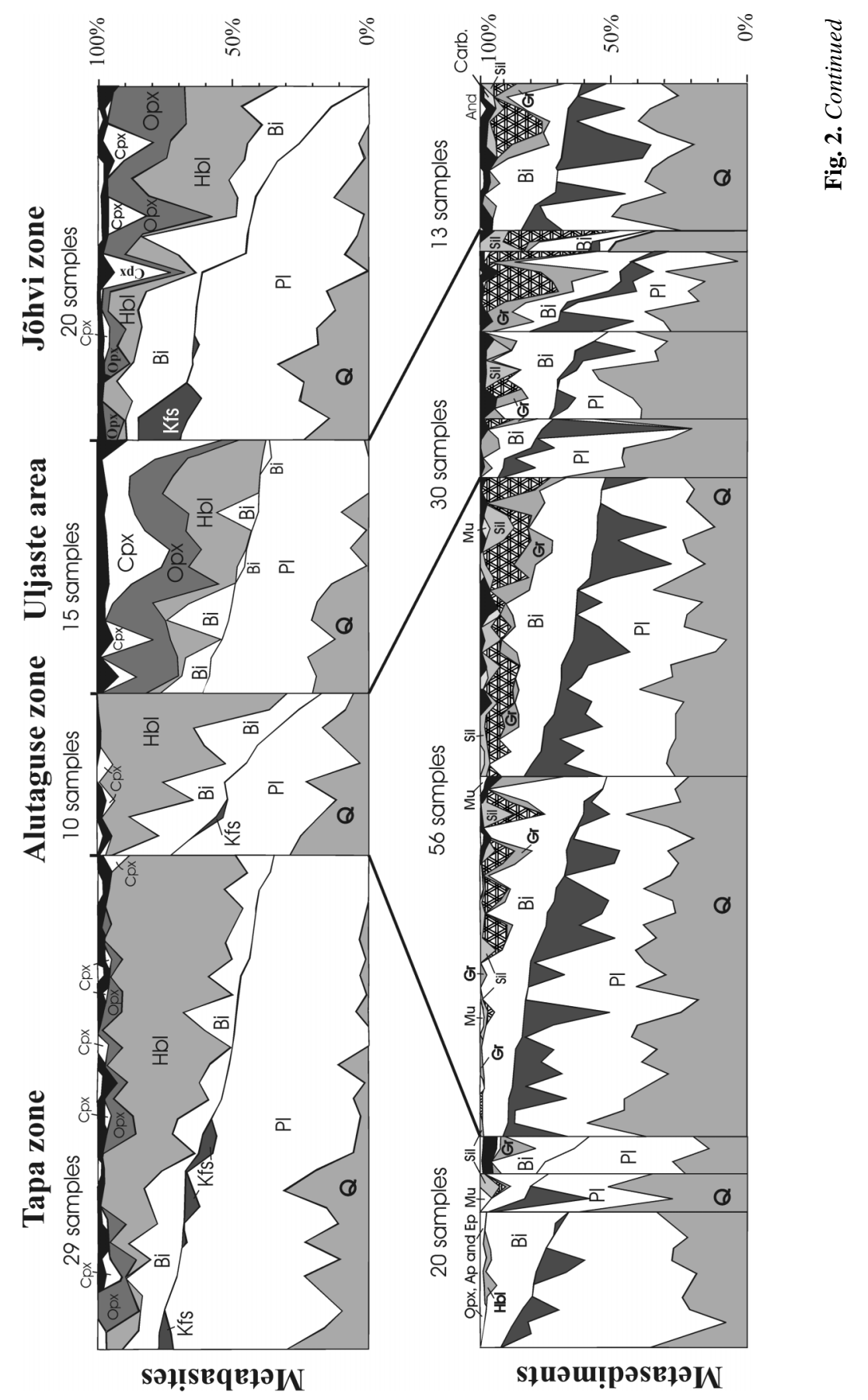




\section{METAMORPHIC FACIES AND PRESSURE-TEMPERATURE CONDITIONS OF METAMORPHISM}

Based upon the mineral parageneses and chemical compositions of minerals (wet chemical analysis of garnet, biotite, and amphibole monomineral fractions) and the use of different geothermometers and geobarometers, the peak metamorphic conditions in main structural zones of the Estonian basement were estimated (Koppelmaa et al. 1978; Puura et al. 1983; Klein 1986). The data obtained revealed that high-temperature and moderate-pressure amphibolite facies conditions dominated in the Tallinn and Alutaguse zones. Geothermobarometry of the $\mathrm{Bi}+\mathrm{Gr} \pm$ Sil assemblage and cordierite suggests peak metamorphic conditions at 600-700 ${ }^{\circ} \mathrm{C}$ and 3-5 kbar (Klein 1986; Koistinen et al. 1996).

In South Estonia, the mineral parageneses of intermediate and mafic metavolcanics and Al-rich gneisses correspond to the granulite facies. Widespread garnet and cordierite in these rocks formed by breakdown of biotite and sillimanite, which indicates prograde metamorphism. However, in many places retrograde assemblages have formed in the conditions of the amphibolite facies.

In western Estonia, metabasites of the amphibolite facies dominate. Plagioclasemicrocline migmatites (leucosomes) are widespread in these rocks. However, the latest drill holes in the vicinity of Haapsalu town penetrated the rock complex with granulite facies assemblages (Koistinen 1994), which may be related to a metamorphic dome. In two drill cores, Bi-Hbl-Hyp gneisses, cut by Hyp-bearing granitoid veins (leucosomes) were observed (Koppelmaa \& Kivisilla 1999).

Metamorphic domes in northern and northeastern Estonia diversify the generally amphibolite facies complexes of the Tallinn and Alutaguse zones. Areas with higher-grade metamorphism, which locally reaches the granulite facies, follow the eastern side of the Tapa fault separating the Tallinn and Alutaguse zones, and further extend to the east in the Uljaste area and Jõhvi zone, and the Slantsy area in Russia (Fig. 1). Three detailed drilling profiles (Fig. 3) consisting of 7-8 drill holes each were studied. Two profiles characterize the Tapa-Haljala dome area, and one - the Uljaste area. Monomineral fractions were separated to study the chemical composition (wet chemical analysis) and properties of the main rock-forming metamorphic minerals separated from metapelites and metabasites (Klein 1986). Typologies of zircons in accordance with the rock-forming mineral assemblages were studied (Konsa 1986; Konsa \& Puura 1999). The granulite facies mineral assemblages in the Jõhvi zone have been described earlier (Koppelmaa et al. 1978; Puura et al. 1983).

Within the metamorphic domes, the primary lithologies of metamorphic rocks differ from those of the surrounding common amphibolite facies rocks (Fig. 1; Puura et al. 1983). In the Jõhvi zone and the central part of the Tapa block, metamorphosed mafic volcanic and intrusive rocks are abundant; in the Jõhvi zone also magnetite-rich gneisses with banded iron formation (BIF) structures occur. 


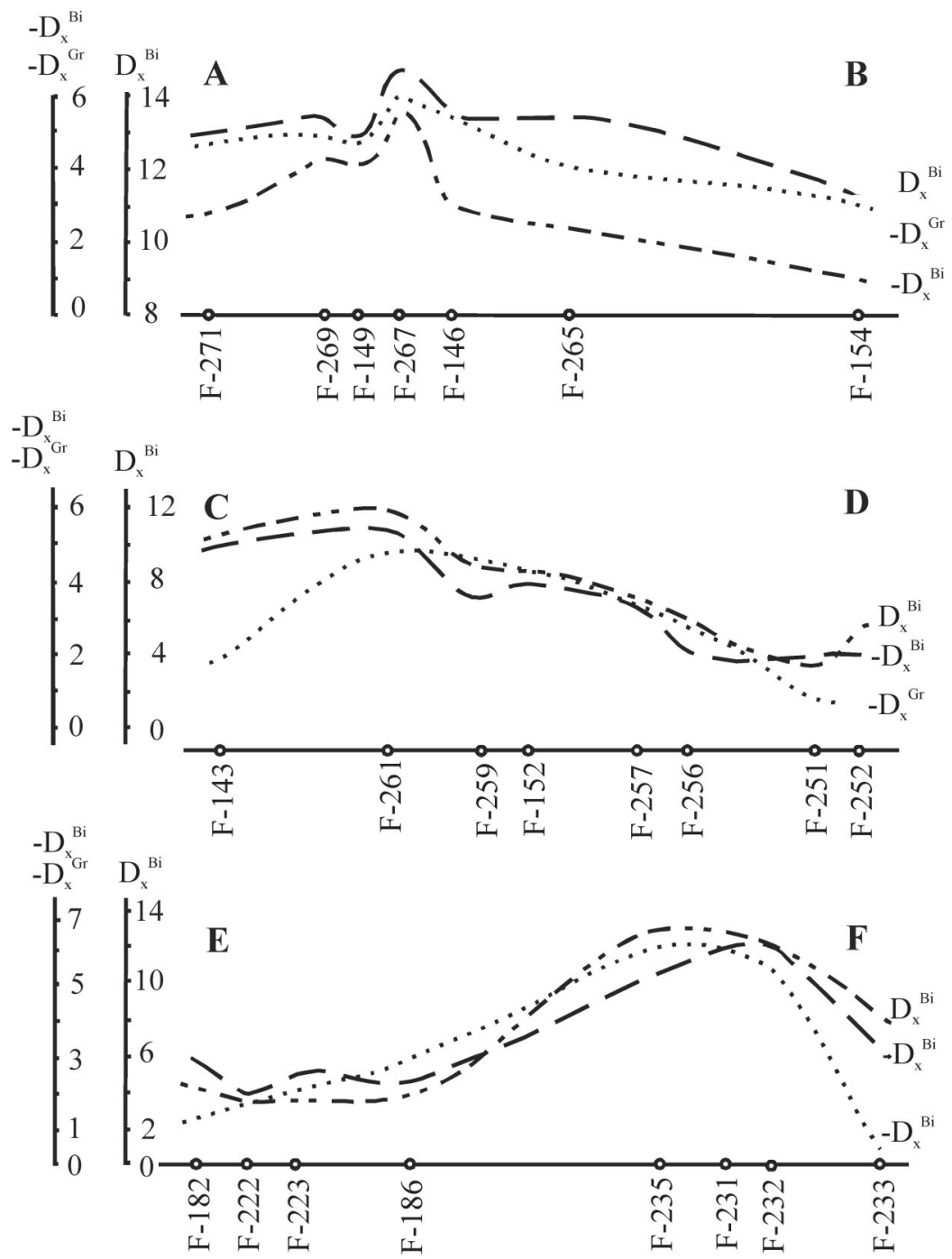

Fig. 3. Changes in discriminant functions calculated from the chemical composition of biotite and garnet (see text) along the Haljala (A-B), Assamalla (C-D), and Uljaste (E-F) profiles.

In the surroundings of the Tapa zone (Assamalla and Haljala areas) and in the Uljaste area metapelites often alternate with quartzites and graphite- and sulphiderich gneisses.

In order to study and map the conditions of metamorphism in the Tallinn and Alutaguse zones in detail, Klein (1986) investigated assemblages of metamorphic minerals, the chemical composition of rock-forming minerals (especially garnet and biotite separated from metapelites, and hornblende and pyroxenes from meta- 
basites) using wet chemical analysis in addition to optical parameters of minerals. In both zones, within the dominant high-grade amphibolite facies areas with $\mathrm{Gr}+\mathrm{Bi}+\mathrm{Sil}+\mathrm{Kfs}$ and $\mathrm{Gr}+\mathrm{Cor}+\mathrm{Sil}+\mathrm{Kfs}$ assemblages, microcline-plagioclase migmatites and small granite bodies are abundant. The areas of lower-grade $\mathrm{Gr}+\mathrm{Bi}+\mathrm{And}+\mathrm{Mu}$ assemblages with Mi-Pl granite-pegmatite veins and erratic migmatite zones are less common. The assemblages corresponding to the transition from amphibolite facies to granulite facies rocks, and those of the granulite facies were studied in the Tapa-Haljala and Uljaste areas (Klein 1986). In order to characterize the changes in metamorphic parameters from the surrounding areas towards the metamorphic domes, a set of discriminate functions calculated from the chemical analyses of minerals were used. Nikitina \& Drugova (1977) have proposed the most sensitive discriminative functions for these purposes based on the composition of garnet (1) and biotite (2). Ušakova (1971) suggested discriminative functions which are based on the composition of biotite (3):

(1) $\mathrm{D}_{\mathrm{x}}^{\mathrm{Gr}}=8.2 \mathrm{Mn}-8.56 \mathrm{Mg}-0.37 \mathrm{Ca}$,

(2) $\mathrm{D}_{\mathrm{x}}^{\mathrm{Bi}}=-19.56 \mathrm{Ti}+1.26 \mathrm{Al}^{\mathrm{IV}}+10.21 \mathrm{Al}^{\mathrm{VI}}-3.89 \mathrm{Mg}$,

(3) $\mathrm{D}_{\mathrm{x}}^{\mathrm{Bi}}=7.876 \mathrm{Si}-10.251 \mathrm{Al}+17.173 \mathrm{Ti}-5.661 \mathrm{Fe}^{3+}-1.404[\mathrm{OH}]$

$$
-4.286 \mathrm{Fe}^{2+}+4.524 \mathrm{Mg}+4.661 \mathrm{~K} \text {. }
$$

The diagrams of discriminative values along the drill hole profiles demonstrate a gradual rise in metamorphic $\mathrm{P}-\mathrm{T}$ parameters from the surroundings towards the centres of the domes: from the northeast to the Haljala dome, from the east (right side of the diagram) to the Tapa dome, and from north to south across the Uljaste dome (Fig. 3). The changes in these discriminative values correspond considerably well to the changes in mineral assemblages.

Two case studies of mineral associations from southern and western Estonia have been performed using microanalysis-based geothermobarometry (Hölttä \& Klein 1991; Kikas 2001). Hölttä \& Klein (1991) studied two drill cores, Kõnnu 300 and Varbla 502, which penetrated the granulite rocks of SW Estonia (Fig. 1). Detailed thin section studies and microprobe chemical studies of main minerals revealed that in both cores the studied assemblages $(\mathrm{Gr}+\mathrm{Hyp}+\mathrm{Bi} \pm \mathrm{Cor} \pm \mathrm{Kfs}+\mathrm{Pl}+\mathrm{Q}$, $\mathrm{Gr}+\mathrm{Cor}+\mathrm{Bi} \pm \mathrm{Sil} \pm \mathrm{Kfs}+\mathrm{Pl}+\mathrm{Q}, \quad \mathrm{Gr}+\mathrm{Bi}+\mathrm{Sil}+\mathrm{Mg}+\mathrm{Pl}+\mathrm{Kfs}+\mathrm{Q} \pm \mathrm{Cor}$, $\mathrm{Gr}+\mathrm{Bi}+\mathrm{Pl}+\mathrm{Q} \pm \mathrm{Kfs}, \mathrm{Gr}+\mathrm{Cor}+\mathrm{Pl}+\mathrm{Q}+\mathrm{Sp}+\mathrm{Mg}$ ) formed at peak temperature near $800^{\circ} \mathrm{C}$. Geobarometers gave pressure estimates close to $6 \mathrm{kbar}$. The results of core-core and rim-rim thermobarometry suggested near-isobaric post-peak cooling of $85-170^{\circ} \mathrm{C}$. Hölttä \& Klein (1991) compared these results with those of Finland. Considerably small Svecofennian granulite terrains in southern Finland were formed at somewhat lower temperature $\left(700-800^{\circ} \mathrm{C}\right)$ and pressure (3-5 kbar). However, Proterozoic Pielavesi granulites of central Finland, which are accompanied by hypersthene granitoids, were formed at $800^{\circ} \mathrm{C}$ and $5-6 \mathrm{kbar}$ and show evidence for near-isobaric cooling (Hölttä 1988). Beside these similar patterns, the Pielavesi granulite area is much smaller than the granulite area in southern Estonia and northern Latvia. The South Estonian granulites definitely 
differ from the Archaean granulite zones in central Finland, where the metamorphic peak conditions were at ca. $750-850^{\circ} \mathrm{C}$ and $8 \pm 1 \mathrm{kbar}$. The Svecofennian granulite areas in Finland, however, differ in the age of peak metamorphism.

R. Hints (Kikas 2001) performed detailed studies of rock-forming mineral assemblages from the Kõnnu 300 (granulite facies, South Estonia) and Valgu 99 (amphibolite facies, West Estonia) cores. These drill holes are located close to the Middle Estonian Fault Zone, virtually on its opposite sides: Kõnnu 300 in the south and Valgu 99 in the north (Fig. 1). In the rather homogeneous sequence of the Kõnnu 300 core, the $\mathrm{Gr}+\mathrm{Opx}+\mathrm{Bi}+\mathrm{Cor}+\mathrm{Pl} \pm \mathrm{Kfs}+\mathrm{Q}$ assemblage is dominant. In some sections of rocks the $\mathrm{Gr}+\mathrm{Cor}+\mathrm{Bi} \pm \mathrm{Sil} \pm \mathrm{Sp} \pm \mathrm{Kfs}+\mathrm{Pl}+\mathrm{Q} \pm$ opaque assemblage was observed. The rock sequence contains a small volume of potassium-rich migmatitic leucosomes. The peak paragenesis is believed to have been formed by partial melting reactions. It is also likely that biotite dehydration reaction is the source for melt formation in metasediments from the Kõnnu and Valgu sections. This type of reaction in metapelites may commence at relatively low temperatures - at $760^{\circ} \mathrm{C}$ (Le Breton \& Thompson 1988). Traces of partial melting imply that melting was the prominent mechanism for dehydration of rocks in the Kõnnu and Valgu drill cores. The coarse-grained peak assemblage with equidimensional porphyroblasts has probably formed under isotropic or weak unisotropic stress conditions. The occurrence of orthopyroxene and hercynite, and specific chemical composition of high-grade phases, such as a high $\mathrm{Ti}$ content in biotite and a high $\mathrm{Al}$ content in orthopyroxene, are in accordance with the other geothermobarometric estimates, which suggests the peak temperature of formation over $800^{\circ} \mathrm{C}$ and pressure of 5-6 kbar (Fig. 4). Alteration of orthopyroxene into biotite-quartz symplectites indicates that the primary cooling after the peak-metamorphic stage has also occurred under similar conditions. With the onset of plastic deformation, extensive re-hydration started and retrograde garnet was generated (Kikas 2001).

The migmatitic gneisses of the Valgu 99 drill core show higher $\mathrm{Al}$ and $\mathrm{Si}$, and lower $\mathrm{Fe}$ and $\mathrm{Mg}$ contents than rocks of the Kõnnu 300 core. The peak mineral assemblages of $\mathrm{Bi} \pm \mathrm{Gr}+\mathrm{Kfs}+\mathrm{Pl}+\mathrm{Sil}+\mathrm{Q} \pm$ opaque and $\mathrm{Bi} \pm \mathrm{Cor}+\mathrm{Kfs}+\mathrm{Pl}+\mathrm{Sil}+\mathrm{Q} \pm$ opaque are most common. Biotite dehydration was favourable for the partial melting. Unlike the Kõnnu drill core, metapelites of the Valgu core attained peak temperatures simultaneously with a strong plastic deformation event that induced the formation of elongated porphyroblasts of garnet and cordierite. Geothermobarometric estimates suggest peak conditions at the upper amphibolite facies: temperature $\sim 700^{\circ} \mathrm{C}$ and pressure $\sim 4.5-5.5 \mathrm{kbar}$ (Kikas 2001).

The high-grade metamorphic rocks have passed several metamorphic stages during the formation of their final mineral assemblages. After the formation of the peak metamorphic associations, at least two retrograde metamorphic associations reflect the decreasing trend of P-T conditions in both drill cores (Fig. 4). Despite 


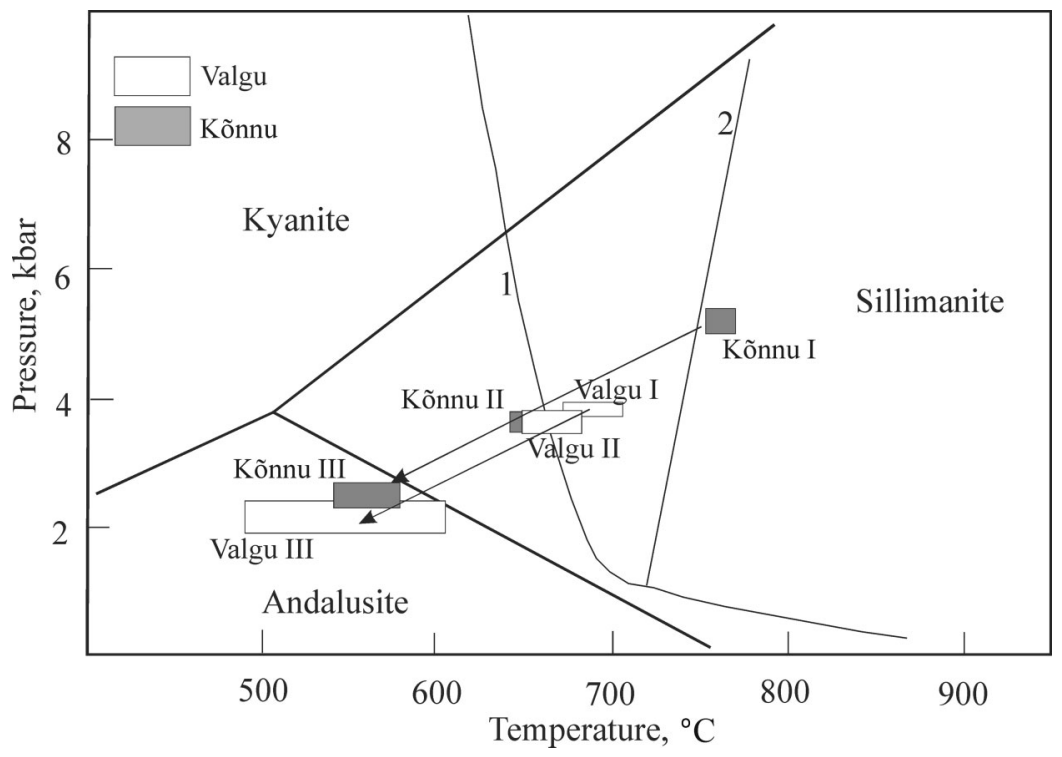

Fig. 4. Pressure-temperature evolution of granulites (Kõnnu 300) and amphibolites (Valgu 99) as determined by the Kleeman \& Reinhardt (1994) geothermometer, and Hodges \& Crowley (1985) geobarometer. The $\mathrm{Al}_{2} \mathrm{SiO}_{5}$ triple point by Holdaway (1971). Curve 1 indicates $\mathrm{H}_{2} \mathrm{O}$ saturated pelite solidus, curve 2 the fluid-absent dehydration melting of biotite (Le Breton \& Thompson 1988).

the difference in the conditions of the peak metamorphism between the Valgu and Kõnnu rocks, their retrograde $\mathrm{P}-\mathrm{T}$ path was similarly expressed by retrograde assemblages whose geothermobarometric estimates suggest $\mathrm{P}-\mathrm{T}$ conditions at around $650-690^{\circ} \mathrm{C}$ and $3.5-4 \mathrm{kbar}$ (second retrograde stage) and $500-600^{\circ} \mathrm{C}$ and 2-2.5 kbar (Fig. 4). The P-T path revealed by the thermobarometric data (see Fig. 4) has a moderate slope. This may indicate cooling with some decompression. Actual peak temperatures for both studied drill cores were probably higher than the biotite dehydration melting curve and thus the pressure values used for the P-T path are probably somewhat lower than the actual pressure values (Kikas 2001). The results of several studies (Klein 1986; Hölttä \& Klein 1991; Kikas 2001) suggest a low-pressure origin for the Estonian granulites, with the average pressures in the range $4-6 \mathrm{kbar}$. This is supported by the lack of high-pressure minerals, such as kyanite, and mineral assemblages, such as orthopyroxenesillimanite.

The difference between the metamorphic stages in the opposite sides of the Middle Estonian fault possibly points to the much deeper exhumation of the South Estonian granulite domain. This is consistent with the results obtained by the structural studies (All et al. 2004). 


\section{THE AGE OF GRANULITE METAMORPHISM}

The Sm-Nd analyses of four whole-rock samples were used to confirm the Palaeoproterozoic origin of the East Baltic granulitic crust (Puura \& Huhma 1993). Further evidence for Proterozoic crustal residence age was provided by Sm-Nd analyses of rapakivi granites (Rämö et al. 1996), and other granitoids and metasediments. Two samples of granulite rocks have been used at the Geological Survey of Finland for mineral separation and U-Pb and $\mathrm{Sm}-\mathrm{Nd}$ isotopic studies in order to specify the age of the granulite facies rocks in southern Estonia. Sample 3005150 from the Kõnnu 300 drill core consists of garnet-orthopyroxene granulite. The mineralogy of this sample has been studied by Hölttä \& Klein (1991), who report peak metamorphic conditions at ca. $800^{\circ} \mathrm{C}$ and $6 \mathrm{kbar}$. Sample 184860 is from the Laeva 18 drill core and represents Opx-bearing Pl-rich rock, also metamorphosed in granulite facies conditions.

\section{Isotope results}

All isotopic analyses were made on hand-picked mineral concentrates. The methods follow standard procedures at the Geological Survey of Finland (e.g. Mouri et al. 1999). The analytical results are given in Table 1 and Fig. 5. A small amount of very clear, short, and pale zircon was extracted from the sample Kõnnu 3005150. Zircon has a low Th content and the morphology is of "granulite type". Three U-Pb analyses of this zircon yielded ${ }^{207} \mathrm{~Pb} /{ }^{206} \mathrm{~Pb}$ ages of $1.84-1.85 \mathrm{Ga}$, and plot close to each other on the concordia diagram (Fig. 5). Although the data are relatively close to concordia, no reliable age can be determined. A U-Pb analysis on monazite provides a concordant age of $1778 \pm 2 \mathrm{Ma}$. Only a very small amount of zircon was extracted from the sample Laeva 184860. This provided one discordant analysis with $\mathrm{a}^{207} \mathrm{~Pb} /{ }^{206} \mathrm{~Pb}$ age of $1776 \mathrm{Ma}$.

Garnets in sample 3005150 are large, $3-10 \mathrm{~mm}$ in diameter, and have numerous inclusions of biotite and quartz (Hölttä \& Klein 1991). From sample 3005150, garnet, plagioclase, and orthopyroxene have been used for Sm-Nd studies (Table 2, Fig. 6), but due to low amounts of $\mathrm{Nd}$ the analysis on Opx was not successful. Five analyses on mineral concentrates and whole rock provided the age of $1728 \pm 24 \mathrm{Ma}(\mathrm{MSWD}=2)$. An analysis on ground and leached garnet (Gr\#3) shows significantly higher Sm-Nd and lower REE contents, compared to the two older analyses on unleached garnet concentrates. This is obviously due to monazite inclusions in garnet. Hölttä \& Klein (1991) reported microscopic observations on such inclusions. However, rejection of Gr\#3 analyses does not significantly change the calculated age. The $\mathrm{Sm}-\mathrm{Nd}$ analyses on plagioclase and whole rock from sample 184860 gave the age of $1766 \pm 56 \mathrm{Ma}$. An analysis on orthopyroxene shows disequilibrium with whole rock. 


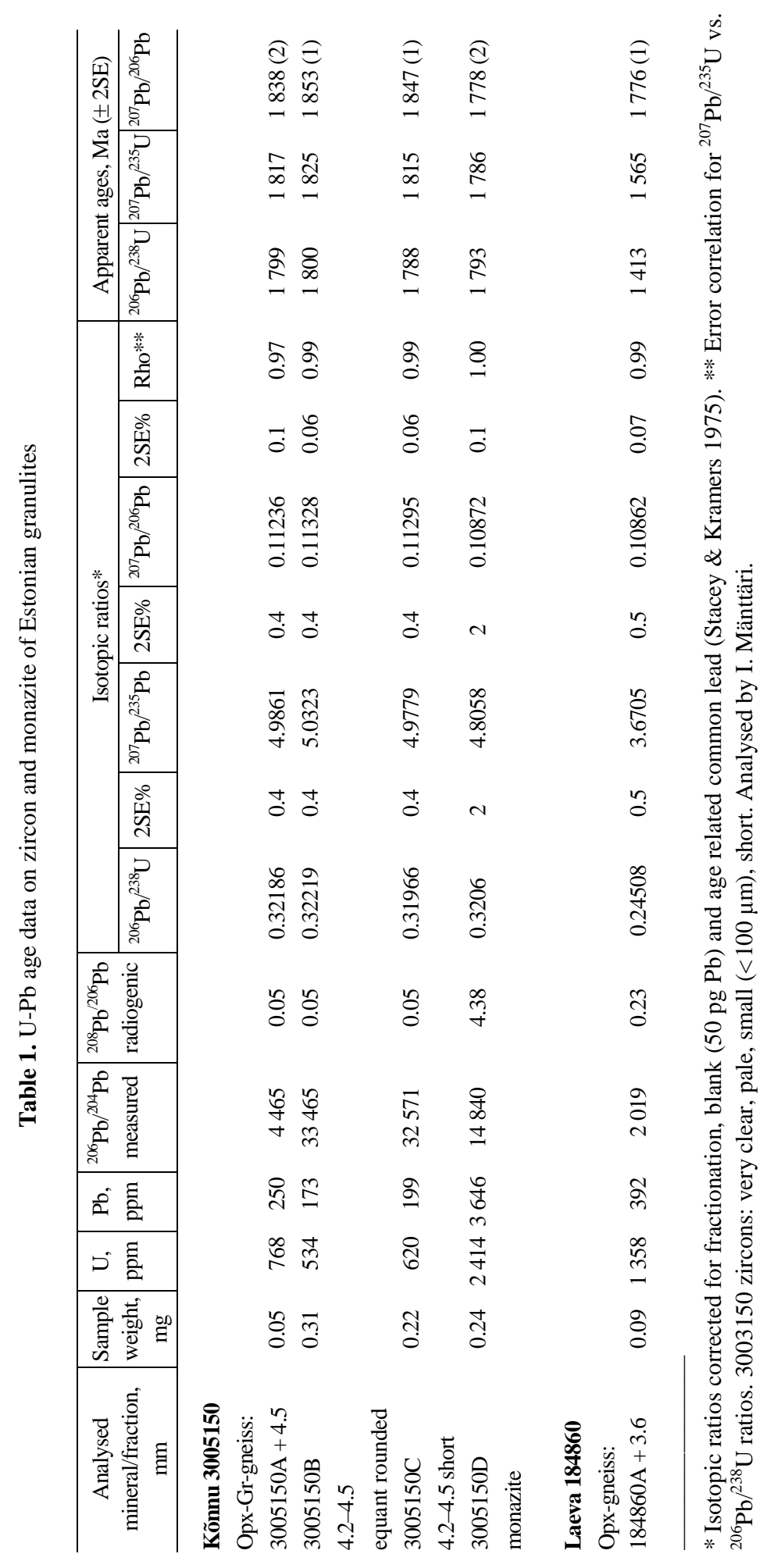




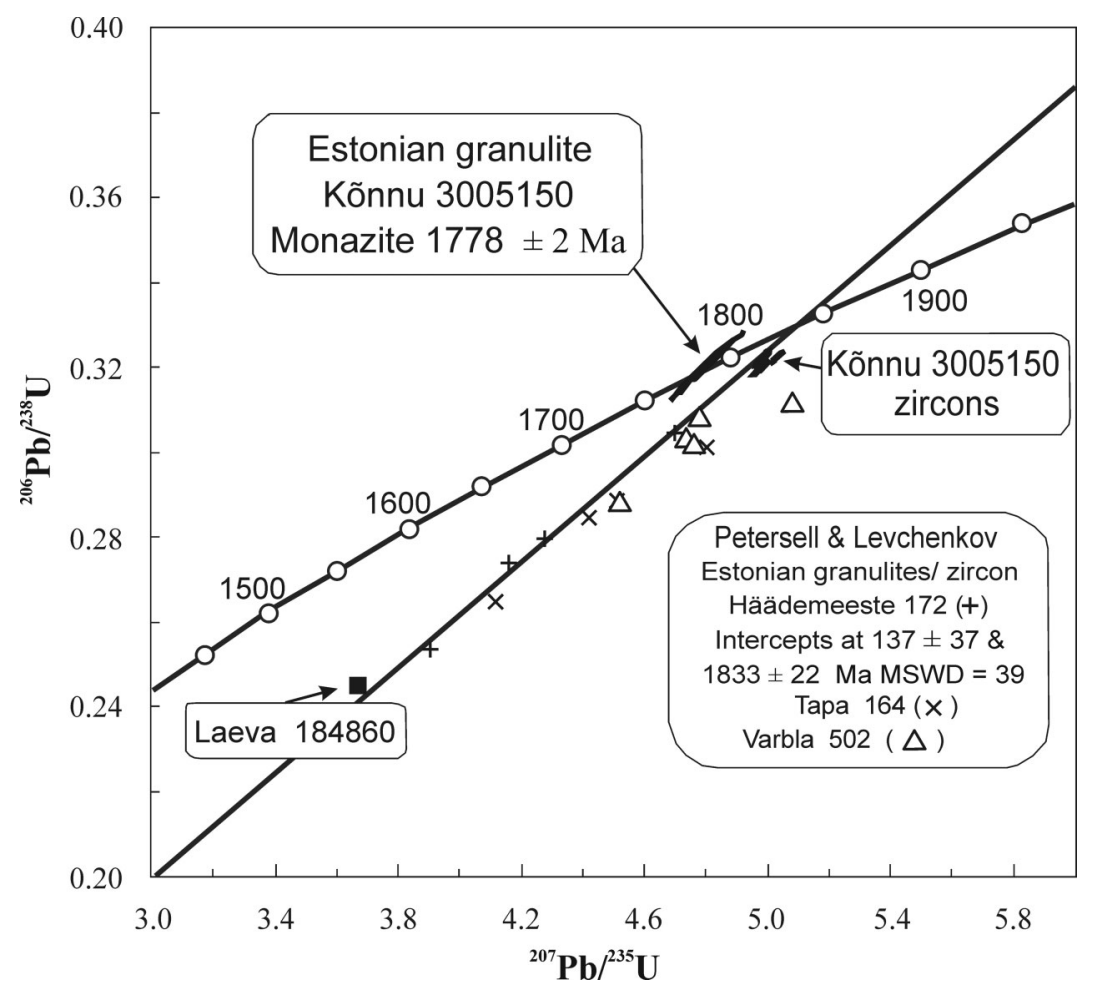

Fig. 5. Concordia diagram of zircon and monazite analyses from the Kõnnu (3005150) and Laeva (184860) granulites. U-Pb zircon results by Petersell \& Levchenkov (1994) on three other Estonian granulitic rocks are shown for comparison: Häädemeeste metavolcanic rock (172), Tapa metavolcanic rock (164), and Varbla metasedimentary rock (502).

\section{Dating the granulite facies metamorphism}

The isotopic results from sample 3005150 can be used for constraining the metamorphic evolution of Estonian granulites. However, it is evident from several recent studies that the interpretation of mineral ages involves problems. It has been shown that monazite can form at different stages during metamorphic evolution, and can preserve ages corresponding to peak temperatures up to granulite facies conditions or may even record prograde growth ages (DeWolf et al. 1996; Spear \& Parrish 1996; Vry et al. 1996; Foster et al. 2002). It has also been suggested that the concept of "thermally reset" monazite ages, or of monazite "cooling ages" should be abandoned (Parrish \& Whitehouse 1999).

The Sm-Nd ages on garnet have been used for constraining the timing of metamorphic cooling. However, there is some debate on the closure temperature. According to Ganguly et al. (1998), no unique closure temperature for the Sm-Nd system in garnet can be stated, but for slowly cooled almandine-pyrope garnet a 


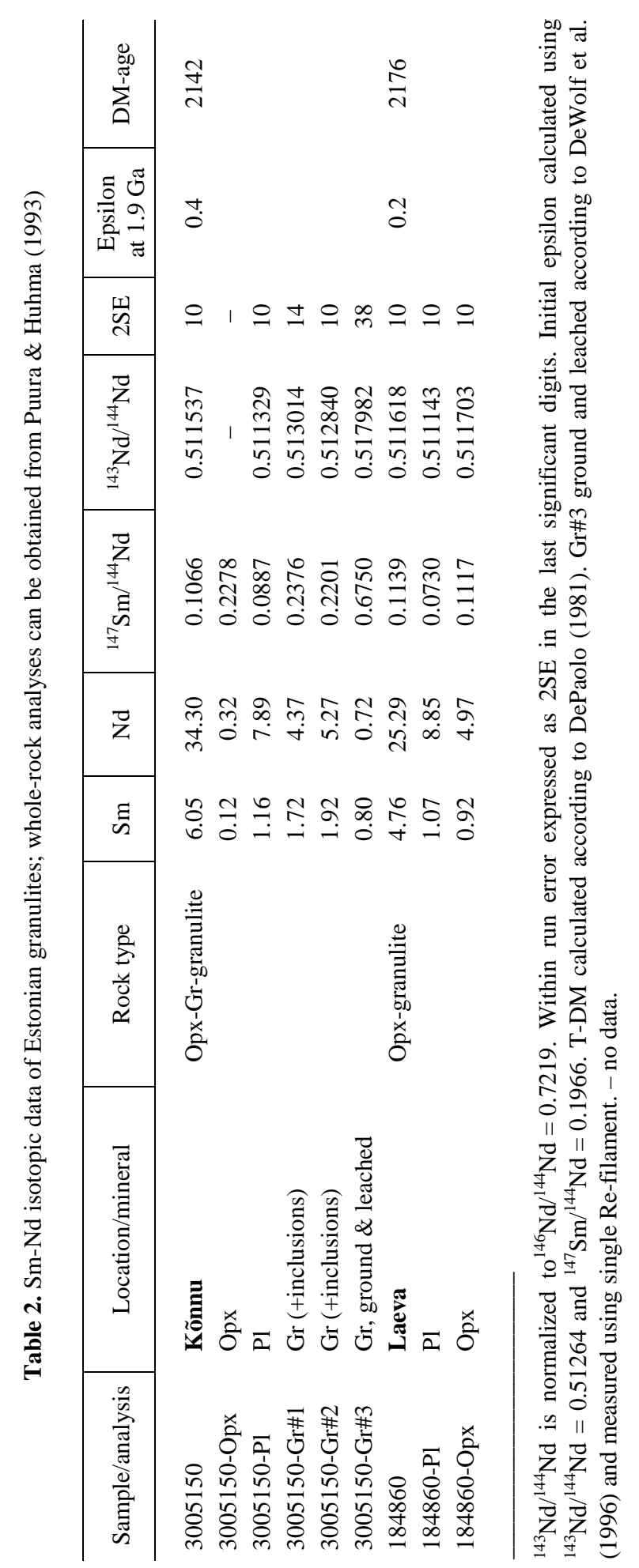




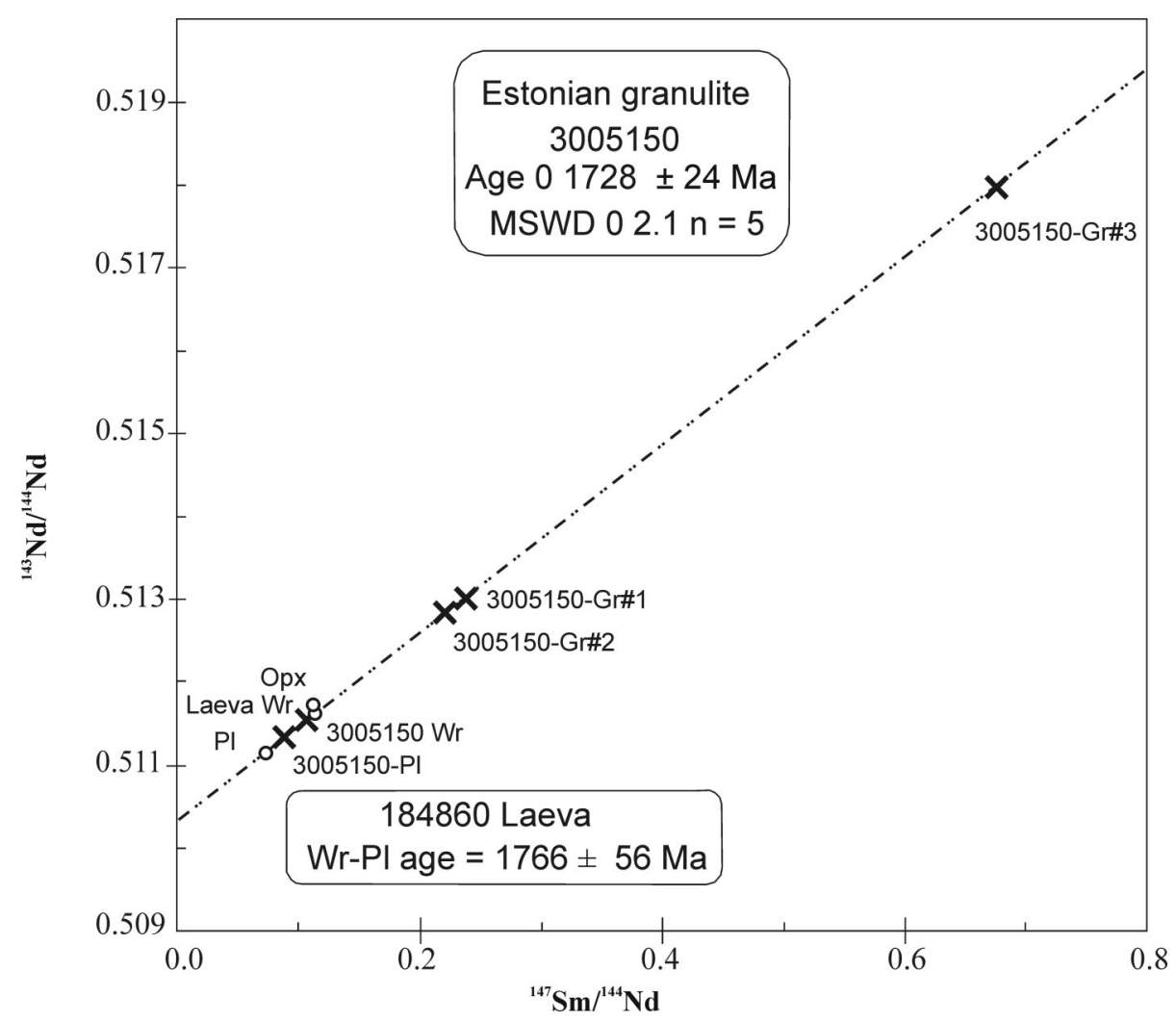

Fig. 6. Sm-Nd isochron diagram for whole rocks and minerals from the Kõnnu (3005150) and Laeva (184860) granulites.

closure temperature of $650-700^{\circ} \mathrm{C}$ can be estimated (Jung \& Mezger 2001; Thöni 2003).

Following the above remarks it is suggested that the age of $1778 \pm 2 \mathrm{Ma}$ for monazite is close to the peak metamorphic stage, ca. $800^{\circ} \mathrm{C}$ and 6 kbar (Hölttä \& Klein 1991). The Sm-Nd age of $1728 \pm 24$ Ma for garnet can be interpreted as the age when the rocks cooled down to the closure temperature of large garnets, ca. $650-700^{\circ} \mathrm{C}$. These results can be compared with the results from the Fennoscandian Shield area. Hölttä \& Klein (1991) suggested that the metamorphic evolution of Estonian granulites resembles that of the NE Svecofennian HaukivesiKiuruvesi complex, where the high-grade metamorphism $\left(800^{\circ} \mathrm{C}\right.$ and 5-6 kbar) took place at ca. $1.88 \mathrm{Ga}$ (Hölttä 1988; Korsman et al. 1988). They also concluded that in the granulite areas of southern Finland (Turku, West Uusimaa, and Sulkava) the rocks were metamorphosed at similar temperatures but slightly lower pressures (700-800 ${ }^{\circ} \mathrm{C}$ and 3-5 kbar; Korsman et al. 1984; Hölttä 1986; Schreurs \& Westra 1986; Väisänen \& Hölttä 1999). 
The U-Pb and Sm-Nd isotopic studies of the Svecofennian granulite areas in Finland clearly show that there are two distinct granulite facies pulses, at ca. $1.88 \mathrm{Ga}$ and ca. $1.83-1.80 \mathrm{Ga}$. The early U-Pb results reported by Korsman et al. (1984) have been confirmed by more recent data. From an older granulite belt in Luopioinen (near Tampere) Mouri et al. (1999) have reported concordant U-Pb monazite ages of $1878 \pm 2 \mathrm{Ma}$ and an average Sm-Nd garnet age of $1870 \pm 20 \mathrm{Ma}$ (five Gr-Wr pairs, Mouri et al. 1999). Migmatites from the Turku area have yielded U-Pb zircon ages of ca. $1.82 \mathrm{Ga}$ (Väisänen et al. 2002). The West Uusimaa migmatites have yielded U-Pb ages of monazites from $1816 \pm 2 \mathrm{Ma}$ to $1832 \pm 2 \mathrm{Ma}$, whereas $\mathrm{Sm}-\mathrm{Nd}$ analysis on garnet gives an average age of $1803 \pm 6 \mathrm{Ma}$ (unpublished data by H. Huhma; Väisänen et al. 2004).

The ages from the Estonian sample 3005150 , i.e. $1778 \pm 2$ Ma for monazite and $1728 \pm 24 \mathrm{Ma}$ for garnet, are clearly younger than any comparable results from Finland. They suggest that the granulite facies metamorphism in southern Estonia is distinct from that recorded in the Fennoscandian Shield.

\section{DISCUSSION}

Metamorphic suites of the Estonian basement belong to the interior of the Svecofennian orogenic domain of about 1.9-1.8 Ga juvenile crust. The earlier suppositions on the Achaean age of granulite terrains within the Baltic-Belarus region (Puura et al. 1976, 1983; Koppelmaa et al. 1978) were invalidated after isotopic studies, especially using Sm-Nd (Puura \& Huhma 1993; Rämö et al. 1996) and U-Th-Pb (Petersell \& Levchenkov 1994) methods. Nironen (1997) presented a regional model of the formation of the Svecofennian juvenile crustal domain through (1) continental break-up of the Late Archaean crust and seafloor spreading during $2.1-1.95 \mathrm{Ga}$, (2) early crust formation at $2.1-1.9 \mathrm{Ga}$, (3) initiation, development, and compression of subduction zones, and island arcs and between-arc sedimentary basins at 1.91-1.82 Ga, and (4) anatectic potassium granite and migmatite formation during the $1.84-1.81 \mathrm{Ga}$ extensional stage. In the Svecofennian interior within the Fennoscandian Shield, the $5 \pm 2$ kbar metamorphism pressure corresponds to a rather uniform $12-18 \mathrm{~km}$ post-peak metamorphism level (Nironen 1997).

Two main regions of metamorphic grade occur in the basement of Estonia. Primary supracrustal lithologies vary in these areas. In the dominating amphibolite facies fields of northern Estonia, the sequence of metavolcanics and -sediments of the Tallinn zone resembles the island arc sequences of southern Finland. Metapelites of the Alutaguse zone may be a continuation of respective lithologies, widespread near the Archaean Karelian Craton in SE Finland and neighbouring St. Petersburg area in NW Russia (Puura et al. 1983; Koistinen 1994; Koistinen et al. 1996). In western Estonia, dominating mafic metavolcanics of the amphibolite facies resemble those of the primary lithologies of South Estonian granulites. In 
general, these zones fit well with the metamorphic zones typical of the Svecofennian interior in the Fennoscandian Shield. The local metamorphic domes reaching up to granulite facies conditions (Haapsalu in western Estonia; Tapa, Uljaste, and Jõhvi in NE Estonia, and Slantsy in NW Russia) also resemble respective complexes in southern and central Finland (Koistinen 1994; Koistinen et al. 1996).

Dominating granulitic mafic metavolcanics of southern Estonia extend towards northern Latvia. A number of similar zones and crustal blocks occur in Lithuania and Belarus. The fact that the peak granulite metamorphism conditions in southern Estonia indicate the pressure up to $6 \mathrm{kbar}$ suggests a much deeper erosional level, of about $20 \mathrm{~km}$ and more, when compared to northern Estonian amphibolites.

However, isotopic ages from the sample Kõnnu 3005150 , i.e. $1778 \pm 2 \mathrm{Ma}$ for monazite and $1728 \pm 24 \mathrm{Ma}$ for garnet, are clearly younger than any comparable results from Finland. They suggest that the granulite facies metamorphism in this particular area or in southern Estonia and Latvia in general is distinct from that recorded in southern Finland.

The anatectic potassium granites and migmatites of southern Finland have their counterparts in northern Estonia (Puura et al. 1983). In southern Estonia, potassium granites occur in the form of charnockites related to peak granulite metamorphism (Kikas 2001). On the other hand, microcline granites and migmatites are occasionally found in fault zones within the dominating granulite terrains of southern Estonia. Relationships between these two occurrences remain open. Orogenic fault zones, such as the Paldiski-Pskov, Tapa, and others, as well as the post-orogenic Middle Estonian fault, control the regional and local (dome-like) metamorphic gradients (see All et al. 2004). The age of these late orogenic faults is younger than the granulite metamorphism.

A variety of peak and retrograde mineral assemblages of Estonian metamorphic rocks (e.g. the presence of zoned zircons) reflecting their multistage evolution, relationships to fault-related deformations with different age, and granitoids still contain a huge amount of possible new information for further specified studies and dating the tectonic and metamorphic events in the history of the Palaeoproterozoic crust. More differences between the evolution of the Svecofennian crust in southern Finland and northern Estonia, on the one hand, and in southern Estonia and Latvia, on the other hand, are expected.

\section{ACKNOWLEDGEMENTS}

V. P. and A. S. acknowledge the financial support from the Estonian Science Foundation (grants Nos. 4417, 4615, and 5817). We are grateful to the reviewers H. Nestor and A. Jõeleht for their critical comments and helpful advice in improving the manuscript. 


\section{REFERENCES}

All, T., Puura, V. \& Vaher, R. 2004. Orogenic structures of the Precambrian basement in Estonia as revealed from the integrated modelling of the crust. Proc. Estonian Acad. Sci. Geol., 53, $165-189$.

DePaolo, D. J. 1981. Neodymium isotopes in the Colorado Front Range and crust-mantle evolution in the Proterozoic. Nature, 291, 684-687.

DeWolf, C. P., Zeissler, C. J., Halliday, A. N., Mezger, K. \& Essene, E. J. 1996. The role of inclusions in $\mathrm{U}-\mathrm{Pb}$ and $\mathrm{Sm}-\mathrm{Nd}$ garnet geochronology: stepwise dissolution experiments and trace uranium mapping by fission track analysis. Geochim. Cosmochim. Acta, 60, 121-134.

Foster, G., Gibson, H. D., Parrish, R., Horstwood, M., Fraser, J. \& Tindle, A. 2002. Textural, chemical and isotopic insights into the nature and behaviour of metamorphic monazite. Chem. Geol., 191, 183-207.

Ganguly, J., Tirone, M. \& Hervig, R. L. 1998. Diffusion kinetics of samarium and neodymium in garnet, and a method for determining cooling rates of rocks. Science, 281, 805-807.

Hodges, K. V. \& Crowley, P. D. 1985. Error estimation and empirical geothermobarometry for pelitic systems. Amer. Mineral., 70, 702-709.

Holdaway, M. J. 1971. Stability of andalusite and the aluminium silicate phase diagram. Amer. J. Sci., 271, 97-131.

Hölttä, P. 1986. Observations on the metamorphic reactions and PT conditions in the Turku granulite area. In Development of Deformation, Metamorphism and Metamorphic Blocks in Eastern and Southern Finland (Korsman, K., ed.). Geol. Surv. Finland Bull., 339, 43-58.

Hölttä, P. 1988. Metamorphic zones and the evolution of granulite grade metamorphism in the early Proterozoic Pielavesi area, central Finland. Geol. Surv. Finland Bull., 344.

Hölttä, P. \& Klein, V. 1991. PT-development of granulite facies rocks in southern Estonia. Geol. Surv. Finland Spec. Pap., 12, 97-131.

Jung, S. \& Mezger, K. 2001. Geochronology in migmatites - a Sm-Nd, U-Pb and Rb-Sr study from the Proterozoic Damara belt (Namibia): implications for polyphase development of migmatites in high-grade terranes. J. Metamorph. Geol., 19, 77-97.

Kikas, R. 2001. Pressure-temperature evolution of high-grade Svecofennian gneisses near Saaremaa Shear Zone. MSc thesis, Institute of Geology, University of Tartu (unpublished).

Kleeman, U. \& Reinhardt, J. 1994. Garnet-biotite thermometry revisited: the effect of A1VI and Ti in biotite. European J. Mineral., 6, 925-941.

Klein, V. M. 1986. Metamorficheskij kompleks svekofennskogo pojasa v severnoj Éstonii. PhD thesis, Institute of Geology, Academy of Sciences of the Estonian SSR, Tallinn (unpublished, in Russian).

Koistinen, T. (ed.). 1994. Precambrian basement of the Gulf of Finland and surrounding area. Map $1: 1$ mill. Geological Survey of Finland, Espoo, 1 sheet.

Koistinen, T., Klein, V., Koppelmaa, H., Korsman, K., Lahtinen, R., Nironen, M., Puura, V., Saltykova, T., Tikhomirov, S. \& Yanovskiy, A. 1996. Paleoproterozoic Svecofennian orogenic belt in the surroundings of the Gulf of Finland. In Explanation to the Map of Precambrian Basement of the Gulf of Finland and Surrounding Area 1:1 mill (Koistinen, T., ed.). Geol. Surv. Finland Spec. Pap., 21, 21-57.

Konsa, M. 1986. Typomorphic variations of zircon in the crystalline basement of Estonia. ENSV TA Toim. Geol., 35, 1-9 (in Russian).

Konsa, M. \& Puura, V. 1999. Provenance of zircon of the lowermost sedimentary cover, Estonia, East-European Craton. Bull. Geol. Soc. Finland, 71, 253-273.

Koppelmaa, H. \& Kivisilla, J. 1999. Geological Map of the Crystalline Basement of North-Western Estonia. Scale 1:200 000. Explanation to the Map. Geological Survey of Estonia, Tallinn.

Koppelmaa, H., Klein, V. \& Puura, V. 1978. Metamorphic complexes of the crystalline basement of Estonia. In Metamorphic complexes of basement of Russian Platform (Dagelaiskiy, V. \& Bondarenko, L., eds.), pp. 43-76. Nauka, Leningrad (in Russian). 
Korsman, K., Hölttä, P., Hautala, T. \& Wasenius, P. 1984. Metamorphism as an indicator of evolution and structure of crust in eastern Finland. Geol. Surv. Finland Bull., 328.

Korsman, K., Niemelä, R. \& Wasenius, P. 1988. Multistage evolution of the Proterozoic crust in the Savo schist belt, eastern Finland. In Tectono-metamorphic Evolution of the Raahe-Ladoga Zone (Korsman, K., ed.). Geol. Surv. Finland Bull., 343, 89-96.

Le Breton, N. \& Thompson, A. B. 1988. Fluid-absent (dehydration) melting of biotite in metapelites in the early stages of crystal anatexis. Contrib. Mineral. Petrol., 99, 226-237.

Mouri, H., Korsman, K. \& Huhma, H. 1999. Tectono-metamorphic evolution and timing of the melting prosesses in the Svecofennian Tonalite-Trondhjemite Migmatite Belt: an example from Luopioinen, Tampere area, southern Finland. Bull. Geol. Soc. Finland, 71, 31-56.

Nikitina, L. P. \& Drugova, G. M. 1977. Linear discriminative functions as criteria for identification of thermodynamic parameters of crystalline rock. In Thermo-barometry of Metamorphic Rocks (Glebovitskiy, V. A., ed.), pp. 107-137. Nauka, Leningrad (in Russian).

Nironen, M. 1997. The Svecofennian orogen: a tectonic model. Precambrian Res., 86, 21-44.

Parrish, R. \& Whitehouse, M. 1999. Constraints on the diffusivity of $\mathrm{Pb}$ in monazite, its closure temperature, and its U-Th-Pb systematics in metamorphic terrains, from a TIMS and SIMS study. In 10th Meeting of European Union of Geosciences, Strasbourg 27.3-1.4.1999. Terra Abstracts, 11, 711.

Petersell, V. \& Levchenkov, O. 1994. On the geological structure of the crystalline basement of the southern slope of the Baltic Shield. Tartu Ülik. Toim. 972. Töid geoloogia alalt, XIV, $16-39$.

Puura, V. \& Huhma, H. 1993. Palaeoproterozoic age of the East Baltic granulitic crust. Precambrian Res., 64, 289-294.

Puura, V., Kuuspalu, T., Birkis, A., Vasiljev, B. A., Gailius, R., Koppelmaa, H. \& Niin, M. 1976. Outlines of the geological structure of the Precambrian basement of the Baltic States. In Geologiya, petrologiya i metallogeniya kristallicheskikh obrazovanij Vostochno-Evropejskoj platformy, Part I, pp. 27-40. Nedra, Moscow (in Russian).

Puura, V., Vaher, R., Klein, V., Koppelmaa, H., Niin, M., Vanamb, V. \& Kirs, J. 1983. Kristallicheskij fundament Éstonii. Nauka, Moscow (in Russian).

Rämö, O. T., Huhma, H. \& Kirs, J. 1996. Radiogenic isotopes of the Estonian and Latvian rapakivi granite suites: new data from the concealed Precambrian of the East European Craton. Precambrian Res., 79, 209-226.

Schreurs, J. \& Westra, L. 1986. The thermotectonic evolution of a Proterozoic, low pressure, granulite dome, West Uusimaa, SW Finland. Contrib. Mineral. Petrol., 93, 236-250.

Spear, F. S. \& Parrish, R. R. 1996. Petrology and cooling rates of the Valhalla complex, British Columbia, Canada. J. Petrol., 37, 733-765.

Stacey, J. S. \& Kramers, J. D. 1975. Approximation of terrestrial lead isotope evolution by a twostage model. Earth Planet. Sci. Lett., 26, 207-221.

Thöni, M. 2003. Sm-Nd isotope systematics in garnet from different lithologies (Eastern Alps): age results, and an evaluation of potential problems for garnet Sm-Nd chronometry. Chem. Geol., 194, 353-379.

Ushakova, E. N. 1971. Biotity metamorficheskikh porod. Nauka, Moscow (in Russian).

Väisänen, M. \& Hölttä, P. 1999. Structural and metamorphic evolution of the Turku migmatite complex, southwestern Finland. Bull. Geol. Soc. Finland, 71, 177-218.

Väisänen, M., Mänttäri, I. \& Hölttä, P. 2002. Svecofennian magmatic and metamorphic evolution in southwestern Finland as revealed by U-Pb zircon SIMS geochronology. Precambrian Res., 116, 111-127.

Väisänen, M., Andersson, U. B., Huhma, H. \& Mouri, H. 2004. Age of late Svecofennian regional metamorphism in southern Finland and south-central Sweden. GFF, 126, 40-41.

Vry, J., Compston, W. \& Cartwright, I. 1996. SHRIMP II dating of zircons and monazites: reassessing the timing of high-grade metamorphism and fluid flow in the Reynold Range, northern Arunta Block, Australia. J. Metamorph. Geol., 14, 335-350. 


\title{
Eesti aluskorra Svekofennia moondevööndid
}

\author{
Väino Puura, Rutt Hints, Hannu Huhma, Vello Klein, Mare Konsa, \\ Reedik Kuldkepp, Irmeli Mänttäri ja Alvar Soesoo
}

Eesti aluskorra kivimilises koostises on selges ülekaalus Svekofennia (Paleoproterosoikumi) orogeensed, kurrutatud metamorfsed kivimid. Põhja-Eestis (Tallinna struktuurses vöötmes) levivad Lõuna-Soomega sarnased amfiboliitse faatsiese settelis-vulkaaniliste kivimite kooslused, mille tõenäoliseks ühiseks tekkekeskkonnaks olid omaaegsed subduktsioonivööndite kaarsaarestikud. KirdeEesti Alutaguse vöötme moondunud liiva- ja savisetete arvel kujunenud alumiiniumirikkad gneisid meenutavad Sankt-Peterburgi ümbruse ja Kagu-Soome samalaadseid gneisivöötmeid, mis kujunesid Svekofennia äärevagumustes Karjala massiivi läheduses. Alutaguse vöötme valdavalt amfiboliitse faatsiese taustal esineb kohalikke, granuliitse faatsiese tasemeni tõusvaid moondekupleid. LõunaEesti aluskorras on valdavad enamasti granuliitse faatsiese tingimustes moondunud aluselised vulkaniidid. Lõuna-Eestist leviv ja Lätissegi jätkuv granuliitne ala on hulga laialdasem kui Lõuna-Soome 1,9-1,8 Ga vanuse Svekofennia orogeeni granuliitse moonde alad. Nagu Soome Pielavesi piirkonnaski, ulatuvad moonde tipptingimused Eestis temperatuurini $800^{\circ} \mathrm{C}$ ja rõhuni $4-6$ kbari. Kuid erinevalt Lõuna-Soomest on Kesk-Eesti Laeva granuliidist eraldatud monatsiidi U-Pb vanus $1778 \pm 2 \mathrm{Ma}$ ja Kõnnu granuliidi granaadi Sm-Nd vanus $1728 \pm 24 \mathrm{Ma}$, seega selgelt noorem. Järeldub, et Lõuna-Eesti granuliitse moonde vööde on märgatavalt noorem kui Lõuna- ja Kesk-Soome Svekofennia moonde alad. 